\title{
The Amyloid $\beta$ Protein Precursor Mutations Linked to Familial Alzheimer's Disease Alter Processing in a Way That Fosters Amyloid Deposition
}

\author{
Steven G. Younkin \\ Division of Neuropathology, Institute of Pathology, Case \\ Western Reserve University, Cleveland, Ohio, USA
}

Younkin, S.G. The Amyloid $\beta$ Protein Precursor Mutations Linked to Familial Alzheimer's Desease Alter Processing in a Way That Fosters Amyloid Deposition. Tohoku J. Exp. Med., 1994, 174 (3), 217-223 — Normal processing of the amyloid $\beta$ protein precursor (BAPP) results in secretion of a soluble $4 \mathrm{kD}$ protein essentially identical to the amyloid $\beta$ protein $(\mathrm{A} \beta)$ that forms insoluble fibrillar deposits in Alzheimer's disease (AD). Strong evidence that amyloid deposition plays a critical role in the development of $\mathrm{AD}$ has come from the identiflcation of familial $\mathrm{AD}$ (FAD) kinderds in which the $\mathrm{AD}$ phenotype cosegregates with mutations in the $\beta \mathrm{APP}$ gene that are located close to the $\mathrm{NH} 2$ or $\mathrm{COOH}$ end of the $\mathrm{A} \beta$ peptide. The location of these mutations immediately suggests that they may cause $\mathrm{AD}$ by altering $\beta \mathrm{APP}$ processing in a way that is amyloidogenic. In a previous study, we found that transfected cells expressing the NH2 side mutant secrete 6 -fold more $4 \mathrm{kD} \mathrm{A} \beta$ than those expressing wild type $\beta \mathrm{APP}$ or $\mathrm{COOH}$ side mutants. We have now shown that the mutations on the $\mathrm{COOH}$ side of $\mathrm{A} \beta$ alter processing to increase secretion of the more amyloidogenic $\mathrm{A} \beta 1-42$ form which constitutes only a small percentage of the total $4 \mathrm{kD} \mathrm{A} \beta$ produced. Thus our data show that all of the FAD-linked $\beta$ APP mutations alter $\beta$ APP processing in a way that increases the likelihood of amyloid formation. Alzheimer's disease; familial; amyloid; precursor; mutation

The $\sim 4 \mathrm{kD}(39-43$ residue) amyloid $\beta$ protein $(\mathrm{A} \beta)$, which is deposited as amyloid in Alzheimer's disease (AD), is encoded as an internal peptide that begins 99 residues from the $\mathrm{COOH}$ terminus of a set of $695-770$ residue glycoproteins referred to as the amyloid $\beta$ protein precursor ( $\beta \mathrm{APP})$. Using cultured cells transfected with $\beta \mathrm{APP}$ expression constructs, we have previously shown the $\beta \mathrm{APP}$ is normally processed into a complex set of $8-12 \mathrm{kD} \mathrm{COOH}$-terminal derivatives that includes a potentially amyloidogenic $\sim 11.4 \mathrm{kD}$ form with $\mathrm{A} \beta$ at its NH2 terminus (Estus et al. 1992; Cheung et al. 1994). More recently (Shoji et al. 1992), we have shown that the $4 \mathrm{kD} \mathrm{A} \beta$ is released in appreciable amounts from transfected cells expressing full length $\beta \mathrm{APP}$ or an $\mathrm{A} \beta$-bearing $\mathrm{COOH}$-terminal derivative and in lesser amounts from cells expressing only endogenous $\beta$ APP.

Received July 18, 1994; revision accepted for publication September 5, 1994. 
Similar results have been reported by several other groups (Seubert et al. 1992; Busciglio et al. 1993; Haass and Selkoe 1993). Thus there is a normal metabolic pathway that produces and releases significant amounts of a soluble $\sim 4 \mathrm{kD} \beta \mathrm{APP}$ derivative essentially identical to the $\mathrm{A} \beta$ deposited as amyloid in Alzheimer's disease.

In rare families, $\mathrm{AD}$ is inherited as an autosomal dominant trait. Strong evidence that amyloid deposition plays a critical role in the development of $\mathrm{AD}$ has come from the identification of familial AD (FAD) kindreds in which the AD phenotype cosegragates with mutations in the $\beta$ APP gene. Three of the FADlinked $\beta \mathrm{APP}$ mutations convert the valine located three residues $\mathrm{COOH}$ to $\mathrm{A} \beta 43$ (val717 in $\beta \mathrm{APP} 770)$, to isoleucine $(\Delta \mathrm{I})$, phenylalanine $(\Delta \mathrm{F})$, or glycine $(\Delta \mathrm{G})$ (Chartier-Harlin et al. 1991; Goate et al. 1991; Hardy and Alzheimer's Disease Research group 1991; Murrell et al. 1991; Naruse et al. 1991; Yoshioka et al. 1991). A fourth double mutation ( $\triangle \mathrm{NL}$ ) alters the lysine-methionine located immediately $\mathrm{NH} 2$ to $\mathrm{A} \beta 1$ (lys670-met671 in $\beta \mathrm{APP} 770$ ) to asparagine-leucine (Mullan 1992). The location of these mutations in close proximity to $\mathrm{A} \beta$ immediately suggests that they may cause $\mathrm{AD}$ by altering $\beta \mathrm{APP}$ processing in a way that is amyloidogenic.

To determine if these mutations do, in fact, alter $\mathrm{A} \beta$ production in the pathway described above, we stably transfected human neuroblastoma (M 17) cells and compared lines expressing normal or mutant $\beta$ APP 695 (Cai et al. 1993). After continuous metabolic labeling for $8 \mathrm{hr}$, cells expressing mutant $\beta \mathrm{APP} \Delta \mathrm{NL}$ showed a 5 -fold increase in the relative amount of the $\sim 11.4 \mathrm{kD} \mathrm{A} \beta$-bearing $\mathrm{COOH}$-terminal $\beta \mathrm{APP}$ derivative, and they released 6 -fold more $4 \mathrm{kD} \mathrm{A} \beta$ into the medium. Similar results have been reported by Citron et al. (1992). These observations (i) provide strong evidence that this mutant $\beta$ APP causes AD because it undergoes altered processing that releases increased amounts of $\mathrm{A} \beta$, and (ii) indicate that the pathway producing $\mathrm{A} \beta$ in cultured cells is highly relevant to $\mathrm{AD}$. More generally, the linkage of $\mathrm{FAD}$ to a $\beta \mathrm{APP} \Delta \mathrm{NL}$ mutation demonstrated to increase $\mathrm{A} \beta$ production greatly strengthens the hypothesis that amyloid deposition plays a central role in the development of all forms of $\mathrm{AD}$.

If amyloid deposition is invariably pivotal in the development of $\mathrm{AD}$, then both the $\beta \mathrm{APP} \Delta \mathrm{NL}$ and the $\beta \mathrm{APP} \Delta 717$ mutations $(\Delta \mathrm{I}, \Delta \mathrm{F}$, and $\Delta \mathrm{G}$ ) should alter $\beta \mathrm{APP}$ processing in a way that is amyloidogenic. Our data showed, however, that transfected M 17 cells expressing $\beta \mathrm{APP} 695 \Delta \mathrm{I}$ do not release increased amounts of $\mathrm{A} \beta$ (Cai et al. 1993). To account for this observation, we proposed that the FAD-linked $\Delta 717$ mutations on the carboxyl side of $\mathrm{A} \beta(\Delta \mathrm{I}, \Delta \mathrm{F}, \Delta \mathrm{G})$ shift cleavage to favor generation of longer $\mathrm{A} \beta \mathrm{s}$ such as $\mathrm{A} \beta 1-42$ or $\mathrm{A} \beta 1-43$. Since these longer $A \beta$ s form amyloid fibrils more rapidly than $A \beta 1-40$ (Hilbich et al. 1991; Burdick et al. 1992; Jarrett and Lansbury 1993; Jarrett et al. 1993), shifting the site of cleavage could result in amyloid deposition without increasing the overall amount of $\mathrm{A} \beta$ produced. 
To test this hypothesis, we used two methods to compare the effect of the $\beta$ APP717 mutations on the relative amounts of $A \beta 1-40$ and $A \beta 1-42,43$ secreted by appropriately transfected M 17 cells (Suzuki et al. 1994). In the first method, $\mathrm{A} \beta 1-40$ and $\mathrm{A} \beta 1-42,43$ were distinguished and quantitated by isolating metabolically labeled $\mathrm{A} \beta$ from conditioned media, digesting the $\mathrm{A} \beta$ with cyanogen bromide to release radiolabeled carboxyl-terminal peptides (A $\beta 36-40$ or A $\beta 36-42,43)$, and analyzing the carboxyl-terminal peptides by RPLC using a C4 column. In the second method, highly sensitive sandwich ELISAs that discriminate synthetic $A \beta 1-40$ from $A \beta 1-42,43$ were employed. With both methods, we invariably observed the relative amount of A $\beta 1-42,43$ produced by $\beta$ APP717 mutants $(\Delta \mathrm{I}$ or $\Delta \mathrm{F})$ to be 1.5 -2.0-times that produced by control $\beta$ APPs. Quantitation of the sandwich ELISA data showed the percentages of A $\beta 1-42,43$ secreted by cells expressing wild type $\beta \mathrm{APP} 695, \beta \mathrm{APP} 695 \Delta \mathrm{I}$, and $\beta \mathrm{APP} 695 \Delta \mathrm{F}$ to be $17.5 \pm 0.5 \%, 25.7 \pm 0.5 \%(p<0.002)$ and $31.4 \pm 0.6 \%(p<0.0002)$, respectively.

Although the $\beta \mathrm{APP} 717$-induced increase in long $\mathrm{A} \beta$ production is relatively modest, in vitro studies by Lansbury and his colleagues (Jarrett and Lansbury 1993; Jarrett et al. 1993) indicate that the impact of this shift on amyloid deposition could be substantial. These studies indicate that $\mathrm{A} \beta$ aggregation into amyloid is a nucleation dependent polymerization (Jarrett and Lansbury 1993; Jarrett et al. 1993), and this type of seeded polymerization can be extremely concentration dependent. Numerous studies have shown that A $\beta 1-42$ and 43 nucleate rapidly compared to A $\beta 1-40$ (Hilbich et al. 1991; Burdick et al. 1992; Jarrett and Lansbury 1993; Jarrett et al. 1993). Thus the modest increase in long A $\beta$ produced by the $\Delta 717$ mutations could substantially increase amyloid deposition in the decades that precede the onset of clinical symptoms in patients who carry these mutations.

With the discovery that $A \beta$ is produced and released by normal processing of the $\beta \mathrm{APP}$, it is clear that $\mathrm{A} \beta$ is an unusual secreted protein released from within the $\beta$ APP through cleavage by $\beta$ and $\gamma$ secretase (Fig. 1). Thus in AD, as is the other known amyloidoses, amyloid deposition is a process in which a secreted protein forms insoluble fibrils that deposit extracellularly. The rate at which amyloid accumulates in the brain will depend on the four processes illustrated schematically in Fig. 2: (i) the rate at which the various $\mathrm{A} \beta$ peptides are secreted, (ii) the rate at which these secreted $\mathrm{A} \beta$ peptides are removed (together these two rates determine $\mathrm{A} \beta$ concentration), (iii) the rate at which $\mathrm{A} \beta$ fibrils form at any prevailing concentration of $\mathrm{A} \beta$, and (iv) the rate at which deposited amyloid fibrils are removed. Recently it has become apparent that a number of extracellular proteins can form complexes with A $\beta$ (Ghiso et al. 1993; Schwarzmann et al. 1993). These $A \beta$-binding proteins are potenitally very important not only because they will influence the fraction of $\mathrm{A} \beta$ that is free but also because they may substantially influence removal of secreted $\mathrm{A} \beta$, the rate at which amyloid 


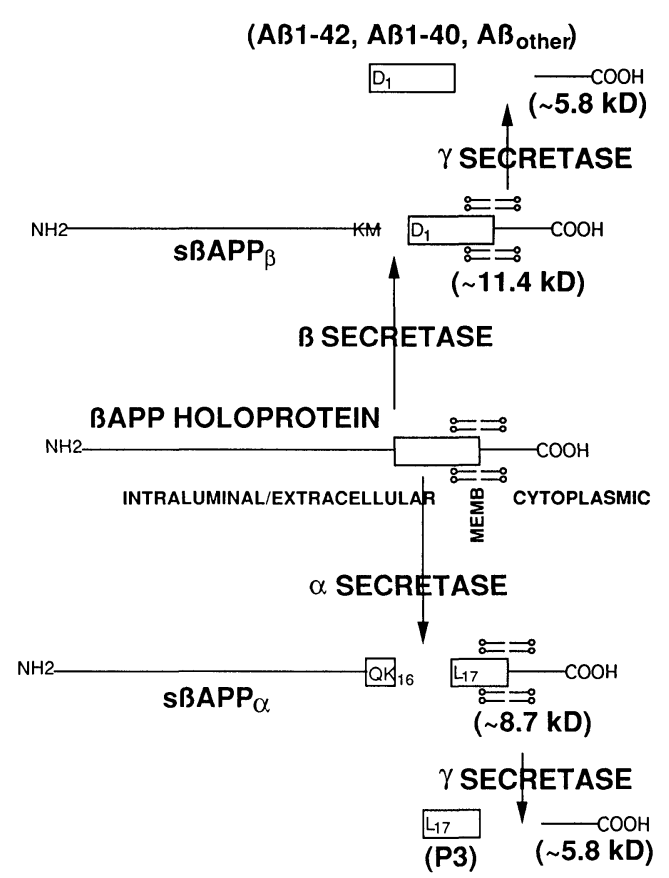

Fig. 1. Pathways processing the $\beta$ APP. Note that $\mathrm{A} \beta$ is produced through cleavage by proteases referred to as $\beta$ and $\gamma$ secretase and that $\mathrm{p} 3$, a smaller peptide not discussed in the text, is produced through cleavage by $\alpha$ and $\gamma$ secretase. The approximate molecular weight of various carboxyl-terminal fragments produced during $\beta \mathrm{APP}$ processing is shown in $\mathrm{kD}$.

fibrils form, or the rate at which amyloid fibrils are removed (Fig. 2).

In the brains of all patients with $\mathrm{AD}$, substantial amounts of amyloid are deposited extracellularly. Thus it is reasonable to propose that amyloid deposition may be an essential element in a serial cascade of age-related pathologic changes that ultimately produces the dementia observed in AD. The FAD-linked $\beta \mathrm{APP} \Delta \mathrm{NL}$ and $\beta \mathrm{APP} 717$ mutations provide strong support for this hypothesis, because each of these genetic changes reliably produces $\mathrm{AD}$, and each enhances amyloidogenesis by increasing secretion of total $\mathrm{A} \beta$ or $\mathrm{A} \beta 1-42$ (Fig. 2). It is likely that trisomy 21 also causes $\mathrm{AD}$ by enhancing amyloid deposition since patients with trisomy 21 have an extra copy of the $\beta$ APP gene and show increased expression of $\beta$ APP (Tanzi et al. 1987) which is normally processed to release $\mathrm{A} \beta$.

Recently it has become evident that there are many individuals with extensive cerebral $\mathrm{A} \beta$ deposition who are not demented. Given the strong genetic evidence favoring the amyloid deposition hypothesis, it is reasonable to propose that these are at risk individuals who have not yet progressed to dementia either because amyloid deposition is recent or because genetic or environmental factors involved in the progression from amyloid deposition to dementia are not favorable. At autopsy, there is some $\mathrm{A} \beta$ deposited in the brain of almost everyone 


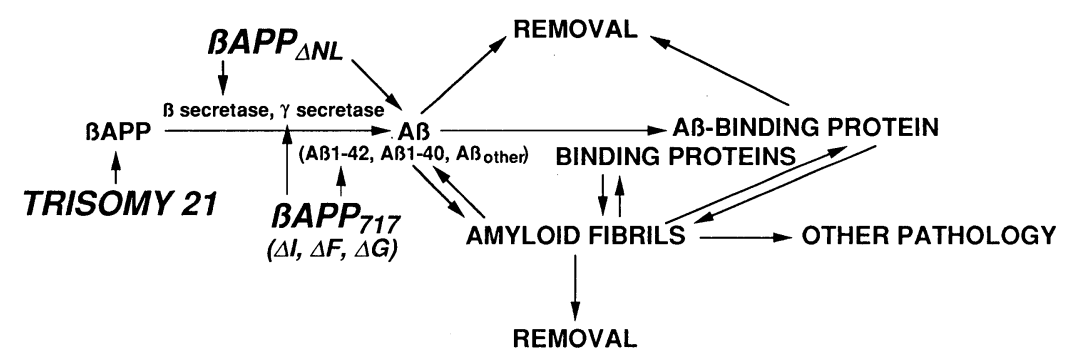

Fig. 2. Processes that influence the amount of amyloid deposited in human brain. There is very little information on many of the processes likely to influence the amount of amyloid that accumulates in the aging human brain. Thus the relative importance of the various processes illustrated is unknown.

over 65 indicating that the conditions needed for minimal amyloid deposition are commonplace in the elderly human brain. The realization that the incidence of $\mathrm{AD}$ may be as high as $50 \%$ in individuals over the age of 85 indicates that with sufficient aging an extraordinary fraction of the population may deposit enough amyloid to produce dementia. Thus it appears that there is a strong tendency toward amyloid deposition in the aging human brain and the relatively subtle differences in the factors that promote amyloid deposition may decide whether or not substantial amounts of amyloid are deposited. Since there appears to be considerable interindividual variation in the pathology that is provoked by amyloid deposition, the challenge for those favoring the amyloid deposition hypothesis is to demonstrate that all $\mathrm{AD}$ can be accounted for in terms of factors that influence amyloid deposition or pathology that is provoked by amyloid deposition.

\section{References}

1) Burdick, D., Soreghen, B., Kwon, M., Kosmoski, J., Knauer, M., Henschen, A., Yates, J., Cotman, C. \& Glabe, C. (1992) Assembly and aggregation properties of synthetic Alzheimer's A4/ $\beta$ amyloid peptide analogs. J. Biol. Chem., 267, 546-554.

2) Busciglio, J., Gabuzda, D., Matsudaira, P. \& Yankner, B. (1993) Generation of bata-amyloid in the secretory pathway in neuronal and nonneuronal cells. Proc. Natl. Acad. Sci. USA, 90, 2092-2096.

3) Cai, Y., Golde, T.E. \& Younki, S.G. (1993) Release of excess amyloid $\beta$ protein from a mutant amyloid $\beta$ protein precursor. Science, 259, 514-516.

4) Chartier Harlin, M.-C., Crawford, F., Houlden, H., Warren, A., Hughes, D., Fidani, L., Goate, A., Rossor, M., Roques, P., Hardy, J. \& Mullan, M. (1991) Early-onset Alzheimer's disease caused by mutations at codon 717 of the $\beta$-amyloid precursor protein gene. Nature, 353, 844-846.

5) Cheung, T., Ghiso, J., Shoji, M., Cai, X., Golde, T., Gandy, S., Frangione, B. \& Younkin, S. (1994) Characterization by radiosequencing of the carboxyl-terminal derivatives produced from normal and mutant amyloid beta protein precursor. Amyloid: Int. J. Exp. Clin. Invest., 1, 30-38.

6) Citron, M., Oltersdort, T., Haas, C., McConlogue, L., Hung, A.Y., Seubert, P., VigoPelfrey, C., Lieberburg, I. \& Selkoe, D.J. (1992) Mutation of the $\beta$-amyloid precur- 
sor protein in familial Alzheimer's disease increases $\beta$-protein production. Nature, 360, 672-674.

7) Estus, S., Golde, T.E., Kunishita, T., Blades, D., Lowery, D., Eisen, M., Usiak, M., Qu, X., Tabira, T., Greenberg, B.D. \& Younkin, S.G. (1992) Potentially amyloidogenic carboxyl-terminal derivatives of the amyloid protein precursor. Science, 255, 726728.

8) Ghiso, J., Matsubara, E., Koudinov, A., Choi-Miura, N.H., Tomita, M., Wisniewski, T. \& Frangione, B. (1993) The cerebrospinal-fluid soluble form of Alzheimer's amyloid beta is complexed to SP-40, 40 (apolipoprotein $\mathrm{J}$ ), an inhibitor of the complement membrane-attack complex. Biochem. J., 293, 27-30.

9) Goate, A., Chartier-Harlin, M.-C., Mullan, M., Brown, J., Crawford, F., Fidani, L., Giuffra, L., Hayes, A., Irving, N., James, L., Mant, R., Newton, P., Rooke, K., Roques, P., Talbot, C., Perciak-Vance, M., Roses, A., Williamson, R., Rossor, M., Owen, M. \& Hardy, J. (1991) Segregation of a missense mutation in the amyloid precursor protein gene with familial Alzheimer's disease. Nature, 349, 704-706.

10) Haass, C. \& Selkoe, D. (1993) Cellular processing of $\beta$-amyloid precursor protein and the genesis of amyloid $\beta$-peptide. Cell, 75, 1039-1042.

11) Hardy, J. \& Alzheimer's Disease Research Group (1991) Molecular characterization of Alzheimer's disease. Lancet, 337, 1342.

12) Hilbich, C., Kisters-Woike, B., Reed, J., Masters, C.L. \& Beyreuther, K. (1991) Aggregation and secondary structure of synthetic amyloid $\beta \mathrm{A} 4$ peptides of Alzheimer's disease. J. Mol. Biol., 218, 149-163.

13) Jarrett, J.T. \& Lansbury, P.T., Jr. (1993) Seeding "one dimensional crystallization" of amyloid: A pathogenic mechanism in Alzheimer's disease and Scrapie? Cell, 73, $1055-1058$.

14) Jarrett, J.T., Berger, E.P. \& Lansbury P.T., Jr. (1993) The carboxy terminus of $\beta$ amyloid protein is critical for the seeding of amyloid formation: Implications for pathogensis of Alzheimer's disease. Biochemistry, 32, 4693-4697.

15) Mullan, M. (1992) Familial Alzheimer's disease: Second gene locus located. Br. Med. J., 305, 1108.

16) Murrell, J., Farlow, M., Ghetti, B. \& Benson, M.D. (1991) A mutation in the amyloid precursor protein associated with hereditary Alzheimer's disease. Science, 254, 97-99.

17) Naruse, S., Igarashi, S., Aoki, K., Kaneko, K., Ihara, K., Miyatake, T., Kobayashi, H., Inuzuka, T., Shimizu, T., Kojima, T. \& Tsuji, S. (1991) Mis-sense mutation Vallle in exon 17 of amyloid precursor protein in Japanese familial Alzheimer's disease. Lancet, 337, 978-979.

18) Schwarzmann, A.L., Gregori, L., Strittmatter, W.J., Enghild, J., Vitek, M.P., Coyle, P.K., Roses, A.D. \& Goldgaber, D. (1993) Sepuestration of amyloid $\beta$-protein. Abstra. Soc. Neurosci., 19, 860.

19) Seubert, P., Vigo-Pelfrey, C., Esch, F., Lee, M., Dovey, H., Davis, D., Sinha, S., Schlossmacher, M., Whaley, J., Swindelhurst, C., McCormack, R., Wolfert, R., Selkoe, D., Lieberburg, I. \& Schenk, D. (1992) Isolation and quantitation of soluble Alzheimer's $\beta$-peptide from biological fluids. Nature, 359, 325-327.

20) Shoji, M., Golde, T.E., Ghiso, J., Cheung, T.T., Estus, S., Shaffer, L.M., Cai, X., McKay, D.M., Tintner, R., Frangione, B. \& Younkin, S.G. (1992) Production of the Alzheimer amyloid $\beta$ protein by normal proteolytic processing. Science, 258, 126-129.

21) Suzuki, N., Cheung, T.T., Cai, X-D., Odaka, A., Otvos, L., Jr., Eckman, C., Golde, T.E. \& Younkin, S.G. (1994) An increased percentage of long amyloid $\beta$ protein secreted by familial amyloid $\beta$ protein precursor ( $\beta$ APP717) mutants. Science, 264, 13361340.

22) Tanzi, R.E., Gusella, J.F., Watkins, P.C., Bruns, G.A., St. George-Hyslop, P., Van Keuren, M.L., Patterson, D., Pagan, S., Kurnit, D.M. \& Neve, R.L. (1987) Amyloid $\beta$ protein gene : cDNA, mRNA distribution, and genetic linkage near the Alzheimer 
locus. Science, 235, 880-884.

23) Yoshioka, K., Miki, T., Katsuya, T., Ogihara, T. \& Sakaki, Y. (1991) The 717 val-lle substitution in amyloid precursor protein is associated with familial Alzheimer's disease regardless of ethnic groups. Biochem. Biophys. Res. Commun., 178, 1141-1146. 